\title{
Subsidising the Cost of Land for Low Income Housing: Some Evidence from Jos, Nigeria
}

\author{
Maren Mallo Daniel ${ }^{1}$, Sanda Nehemiah Yakubu ${ }^{1}$, Celina Onugba Omogor ${ }^{1}$, Adesina Akande ${ }^{2}$ \\ ${ }^{1}$ Department of Estate Management, Faculty of Environmental Sciences, University of Jos, Nigeria \\ ${ }^{2}$ Directorate of Physical Facilities, University of Jos, Nigeria \\ Email: marenmallodaniel@gmail.com
}

\begin{abstract}
This study aims to examine the variables that influence the application of land and infrastructure subsidy for low-income housing provision in the city of Jos, Nigeria. Data was collected by conducting interviews with the representatives of the relevant government agencies and those of the house building companies. This was transcribed and examined alongside documentary evidences. The analysis was conducted in line with the study's objectives: The first was to examine how the policy for subsidising the cost of land applies in the local context in Jos. The data examined in connection to this objective suggest that there is an absence of a uniform approach to the application of the subsidy policy by the three tiers - federal, state and local — of government. The approaches adopted by the federal and state government agencies were seen not to be effective in supplying the subsidies needed by private developers. The second objective was interested in scrutinising the variables influencing the arrangement for subsidising the cost of land in Jos. The data analysed confirms that the lack of proper understanding of land subsidy policy among government officials, the absence of political will on the part of State and Federal government agencies, the absence of transparency and accountability on the part of government officials, the absence of legislation in support of the subsidy policy, and bureaucratic constraints were the key variables influencing the subsidy arrangement in Jos. These findings were examined and some recommendations were proffered.
\end{abstract}

Keywords: Land Use Policy, Subsidies, Low-income housing, Jos, Nigeria

\section{INTRODUCTION}

For close to two decades now, the Federal Government of Nigeria has made efforts at addressing the hindrances to accessing land for low income housing. For instance, the 1991 National Housing Policy which was revised in 2006 and 2012 were all designed to promote local level collaboration between government authorities, house builders and land owners in the provision of subsidised land for low income housing. It is assumed that this strategy would mitigate the obstacles militating against access to land by house builders, and effectively lead to the production of low-income housing (FRN, 2006 and 2012). The practical format of the subsidy policy requires the state and local government authorities who are responsible for the regulation of land use and provision of housing development subsidies to buy land from the native owners, create the layout, and provide basic services before selling to house builders and individuals at a low prices so as to facilitate housing provision at the local level (FRN, 2012). It is assumed that subsidising the cost of land should enable developers to build houses of varying sizes and prices, not exceeding N5million (US\$31,250) (FGN, 2006 pp.34-37). The 
assumptions are evidently difficult to apply and have often failed in practice. The case of Jos city is brought to focus in this article.

This study examines the application of this policy proposal in the city of Jos, Nigeria. Jos, the capital of Plateau State is located in the central region of Nigeria. The city's population was estimated at 1.4 million at the time of the study (Daniel, 2014 p.90). The city of Jos, like other cities in Nigeria, is experiencing rapid urbanisation and shortage of adequate and affordable housing. The proposed solution requires the Federal Government of Nigeria as well as the 36 federating states of Nigeria and their local government councils (totalling 774 in all), to provide land and infrastructure subsidies to private house builders for the supply of low-income housing. This proposal has been experimented for over a decade in the city Jos but limited successes have been realised (FRN, 2005; Daniel 2015). To substantiate this, the combined supply of low income housing by the five private developers who had entered into partnership with the government authorities in Jos was below 500 units as at the time of this study (FRN, 2005; Daniel, 2015). This is far below expectation and it is a main reason for the choice of Jos within this study.

This article aims to achieve two objectives. The first is to examine how the policy proposals for subsidising the cost of land apply in the local context in Jos; and secondly, to scrutinise the variables influencing the arrangement for subsidising the cost of land in Jos. Prior to the examination of these objectives, it is necessary to provide a brief context on Nigeria's Land Use Policy in order to inform readers. Following this, a review literature on land administration systems in the sub-Sahara Africa region will be conducted in order to place this study within a broader African context.

\section{LAND USE POLICY IN NIGERIA: A BRIEF HISTORICAL ACCOUNT}

On 27th March, 1978, the then military administration in Nigeria promulgated the Land Use Decree (now referred to as the Land Use Act - LUA - under the Laws of the Federation of Nigeria 1990). Prior to the promulgation of the LUA in 1978, there were public concerns over the challenges of accessing land at affordable cost. This problem affected individuals, commercial farmers, industrialists, estate developers as well as government (Umezulike, 2011). To address this concern, the military administration promulgated the LUA with ultimate goal of: "... vesting all Land comprised in the territory of each State (except land vested in the Federal Government or its agencies) solely in the Governor of the State, who would hold such Land in trust for the people and would henceforth be responsible for allocation of land in all urban areas to individual residents in the State and to organisations for residential, agriculture, commercial and other purposes while similar powers with respect to non-urban areas are conferred on Local Governments" (FRN, 1978).

Daniel (2015) citing Francis (1984) observes that all forms of customary land holdings that existed in Nigeria became unified in the statutory right of occupancy to become the LUA of 1978. This development led to considerable problems as highlighted by Francis (1984): “...the intentions behind the LUA seem to have been neither unitary nor coherent, and its real potentials as an instrument of expropriation are shrouded in rhetoric of equality and justice". Further, "...distinction between legislative intention and effect is an impact of the disjunction between the national and the local; between the State pretensions and community impermeability; or, in their normative aspects, between law and custom" (Daniel, 2015 citing Francis, 1984 p. 5 in).

Lastly, Francis (Ibid. p. 6) observed that "the ideological construction of the LUA is at variance with potential consequences in a manner which exactly parallels the central ambiguities in the Decree drafting. Furthermore, there is divergence of interest between the bureaucratic powers established to administer the Decree and mass rural dwellers who are its potential victims", Francis concluded. Several writers (including Oshio, 1990, Ikejiofor, 1998, Mamman, 2009, Umezulike, 2011 and Otubu, 2010) concur with Francis. Otubu (2010) 
specifically notes that "the LUA is nothing but a nationalisation instrument which took away the right of ownership and management from the citizens and vested it on the state. It has turned property owners into tenants over land and also impoverished citizens as it sought to remove the economic and wealth creation attributes of land". More so, the power bestowed on Governors by the Act was enormous to the extent that it overshadowed and made nonsense of the power vested in the Local Government Authorities to administer rural land (Umezulike, 2011).

Over time, government authorities have come to appreciate the problems associated the LUA. One of the difficulties is with regard to the challenge of acquiring land for urban and rural development projects, and this was a constraining factor during the National Development Plans of 1975-1980 and 1982-1986 (Mamman, 2009). Other dimension of the problems is in connection to the financial implications of compensating people whose lands are acquired for government projects, and this has long been documented in academic research (Agbosu,1988). As a result of the dilemmas in the LUA, the compensation claimed and paid by governments during compulsory acquisition were generally much higher than the true opportunity cost of comparable land. Furthermore, the study of Onibokun, Agbola and Labeodan (1989) found that land acquisition for site-andservices schemes over the decades of 1980s and 1990s was a critical delaying factor in most cases.

Nigeria's land use policy designers thought that all these problems could be addressed if state and local authorities are able to enter into effective partnership with native land owners and private house builders at the local level. Secondly, it is also assumed that if state and local government authorities are made to take responsible for the provision of land and infrastructure to private developers, the cost of housing production would substantially be lowered (FRN, 2012). Unfortunately, these assumptions have held only partially in the city of Jos (Daniel, 2015) and this is concern is the key motivator for this study.

\subsection{Land Administration and the Supply of Housing Land in sub-Sahara Africa}

Land is the ultimate source of wealth and that is why the developed societies of Europe and North America have been able to unlock the wealth in their lands by creating effective systems for land administration. An effective system of land administration promotes the growth of land market and the effective use of land. It also ensures that land tenure is secured and it makes possible the growth of a mortgage operation (United Nations Economic Commission for Europe - UNECE, 2005). The benefits that are derivable from a good land administration system are many. Some of the benefits include the guaranteeing of property ownership and security of land tenure, effective landed property taxation system, guaranteeing of credit, the growth of an effective land market, the protection of government land, the minimising of disputes arising from land, the promotion of land reforms, the ensuring of orderly development on land, and the production of statistical data (UNECE, 1996). It also promotes cost effective means of land transfer (UNECE, 2005).

Literature (UNECE, 1996, 2005, Stanfield, Underwood, Gunaskera, and Ernst, 2008) indicates that the advanced nations have developed an effective system of land administration which eliminates the problems affecting housing provision. While this progress is being experience by the developed countries, it is not so with the developing countries where land administration systems are still being developed. The developing countries of the sub-Saharan Africa regions are still grabbling with multiple issues. These problems have been highlighted by van Asperen (2014) as follows: rapid rates of urbanisation, ineffective land management tools, difficulty of getting access to land for housing development, ineffective land registration system and poor urban planning arrangement. These problems have led to lack of orderly development in most peri-urban cities of sub-Sahara African countries. As a result, people do acquire land through arrangements that do not guarantee tenure security. And the lack of tenure security constitutes a considerable problem to accessing finance for housing provision. This was found to be case in Uganda, Kenya, Ghana, Namibia, Zambia and Botswana. However, Botswana seems to have overcome this challenge (van Asperen, 2014). 
A survey of literature also suggests that most of land supply issues arise from ownership tussles between the Native land owners and government authorities. In Nigeria, this problem is well documented in literature (see Oshio, 1990, Ikejiofor, 1998, Mamman, 2009, Umezulike, 2011 and Otubu, 2010); it is also well documented in the literature originating from Burkina Faso and Niger (Quedraogo, 2006a), Kenya (Kameri-Mbote, 2006), Zambia (Mbinji, 2006) and Tanzania (Wily, 2003). In these countries, the conventional land administration systems appear not to fit customary structures of groups and family rights, and as a consequence, disputes arising from land ownership tussles remain a key deterrent to land supply (Augustinus and Deininger, 2006). Another problem that has been identified among the sub-Sahara African countries is weak integration across land administration functions and between different levels of government. This problem is found to impede the supply land for housing in most Nigerian cities (Agunbiade, Rajabifard, and Bennet, 2014). A similar land administration lapse is evident in Dodoma, the capital city of Tanzania. Kiduanga (2014) examine the role of the Dodoma Municipal Council and the Capital Development Authority in managing land for developing Dodoma and findings indicate that there was weak administrative structure and low coordination in the arrangement for delivering land for development. It is with a view to addressing this concern that Agunbiade, Rajabifard, and Bennet (2014) developed a framework for the integration of land administration processes and promoting collaboration among land administration agencies. This is considered essential for the effective delivery of developable land for housing production. However, it is too early to conclude that this framework would address the land supply problems in the sub-Sahara Africa as it has not been put to use in any country yet.

There is a consensus in literature that the conventional land administration system has failed to operate effectively among the sub-Sahara African countries. This problem is well recognised by political leaders and government authorities in African states. Accordingly, a number of the sub-Sahara African countries have introduced various forms of reforms that are tailored at tackling the problem. For instance, the government of Burkina Faso started a policy dialogue in 2001 with a view to drafting a new land tenure law. Multiple stakeholders were involved in the policy dialogue and it was agreed that all stakeholders (government, farmers, communities, and the private sector) should participate in land administration so as to ensure equity (Quedraogo, 2006b). In Kenya, a new Registered Land Act (RLA) was passed with the objective of addressing the issue of excluding women from acquiring land titles. Prior to the passage of the RLA, land titling processes had excluded women from obtaining titles (Kameri-Mbote, 2006). In 2001, the Zambian authorities commissioned the agency responsible for land administration to draft a New Land Use Policy. The new policy was aimed at eliminating the obstacles of accessing land and land titles by women, youth, and other disadvantaged groups. Unfortunately, the consultations that lead to the new Land Use Policy did not adequately provide for the participation of the target groups (Mbinji, 2006).

Wily (2003) documents an important land reform programme that is evident across the sub-Sahara Africa region. This reform programme has to do with localising land administration and management. For example, Tanzania enacted a basic new land policy in the form of the Land Act and the Village Land Act in 1991. This legislation came into effect in 2001 with the main objective of devolving the authority for land administration, management and dispute resolution at the community level (Wily, 2003). Similar development is recorded in Eritrea, Ethiopia, Burkina Faso, Zambia, Rwanda, Niger, Mali, Uganda, Kenya, Tanzania, Zimbabwe, Namibia, Lesotho, Swaziland, Ghana, South Africa, Angola, and Mozambique among others (Wily, 2003). Citing the example of Niger, Quedraogo (2006a) observes that the localising of land administration and management is gradually replacing the failure of state land monopoly; it has brought some improvement in the system of land management, and has created flexibility and legal pluralism in land administration. Quedraogo also documents that the localising of land administration has helped the communities to create "local rules" for land resource management and local land dispute resolution that is built on the knowledge and legitimacy of local institutions such as traditional chiefs, heads of lineages, and religious authorities. 
The key impediments to the supply of housing land in Nigeria have previously been highlighted as well as the policy designed by the federal authorities to tackle the problem at the local level. Prior to examining how the authorities in Jos are deploying the proposed policy provisions to tackle land supply issues, it is necessary to highlight the critical problems of housing provision in Jos. The problems include the rocky terrain in the city, inability of government to provide basic infrastructure in residential neighbourhoods and places earmark for future development, land ownership tussles, unregulated land market, rise in informal housing stock (Umezulike, 2011; Otubu, 2007), poor development control, disorderly development (Dung-Gwom, 2007a) and delays in land registration (Dung-Gwom, 2001). Furthermore, a large area of land is damaged by unregulated tin mining activities. The land affected was estimated at 316 square kilometres and this now requires reclamation (Alexander, 1990 p. 44) but the government authorities have not been able to do this.

Illegal tin mining is still ongoing (Mallo, 2012) thereby causing a further reduction in the size of flat lands that can be used for housing provision and other forms of development. The lands damaged as a result of tin mining contain stagnant water which breeds mosquitoes. Some of the tin mining regions contain radioactive materials which are hazardous to human lives (Wapwera, et al, 2011, NGO News Africa, 2009; Raufu, 1999).The attempts to reclaim land affected by tin mining activities has been slow. However, some of the mining ponds are used for dry season irrigation agriculture (Dung-Gwom, 2007b). It is sad also that some have become death traps to those people who are unlucky to fall in them and become their death trapped (Adiuku-Brown, 1999).

The city of Jos is urbanising very quickly and if the un-reclaimed mining ponds are reclaimed, they could help in improving the supply of land for housing development and other forms of investment. But because the local authorities are unable to finance the reclamation of the wasted land, the people are left with no option than to build houses around the ponds. This is a worrying situation because those people residing around the mining ponds are experiencing very poor housing conditions (Wapwera, et al, 2011). The responsibility of providing land for housing development lies with the state and local government authorities. This is the position of the national housing policy (FGN, 2006). It is important therefore to investigate how the housing activities of the government authorities in Jos are consistent with the national housing policy provision. This study is set to achieve this.

\section{METHODOLOGY}

Primary and secondary data were used in conducting the study. The primary data was generated through semistructure interviews with stakeholders whose activities are relevant for the subsidising of land and infrastructure for housing in Jos. The duration of interviews varied from one respondent to another; however, they were all within the range of 20 to 30 minutes. The interviewees were purposely selected based on their experience and there were two groups of respondents: the first group comprised of government officers who were involved with land administration and the implementation of housing policy in Jos; the second group was comprised of private housing developers who had entered into partnership with government in order to provide housing for the low income groups in Jos. Further details about the interviewees are provided on table 1. The purpose of the interviews was to examine the experiences of subsidising the cost of land and infrastructure for low-income housing in Jos. The interviews were also intended at scrutinising the variables that influence the outcomes of the national housing policy proposals in Jos. Secondary data on the records of land title applications and approvals in the last ten years was used to corroborate the interview evidence. This was collected from the State Ministry of Lands, Survey and Town Planning.

The qualitative data was analysed thematically. The data, which was recorded on a voice recorder, was transcribed into a text and then followed with a thorough reading to see how much value it adds to the study's objectives. The next level of analysis involved organising the data according to the questions asked while conducting the interviews. This led to the next level of analysis which focused mainly on categorising information according to emerging themes. This was followed with the identification of patterns and the 
drawing of connection within and between categories. The last stage was the interpretation of results. The procedures followed are consistent with those outlined by Taylor-Powell and Renner (2003) and Gray (2009). The secondary source materials include policy statement and reports published by government authorities. These were collected from the websites of the publishing organisations and used to corroborate evidence obtained from interviews. They were also used in the illustration of trend in land title applications and approvals.

Table 1: Profile of Interviewees

\begin{tabular}{|c|c|c|c|}
\hline $\begin{array}{l}\text { Interviewees' } \\
\text { Identification }\end{array}$ & Employment/Designation & $\begin{array}{l}\text { Year of } \\
\text { Experience }\end{array}$ & Sex \\
\hline $\mathrm{F}$ & $\begin{array}{l}\text { Federal Comptroller, Ministry of Lands, } \\
\text { Housing and Urban Development (Now } \\
\text { Federal Ministry of Power, Works and } \\
\text { Housing), Jos office }\end{array}$ & $\begin{array}{l}26-30 \\
\text { years }\end{array}$ & Male \\
\hline S1 & $\begin{array}{l}\text { Director, Lands (Plateau State Ministry of } \\
\text { Lands, Survey and Town Planning) }\end{array}$ & $\begin{array}{l}26-30 \\
\text { years }\end{array}$ & Male \\
\hline $\mathrm{S} 2$ & $\begin{array}{l}\text { Assistant Director, Estate (Plateau State } \\
\text { Ministry of Housing and Urban } \\
\text { Development) }\end{array}$ & $\begin{array}{l}21-25 \\
\text { years }\end{array}$ & Male \\
\hline L1 & $\begin{array}{l}\text { Senior Planning Officer (Lands Unit), Jos } \\
\text { South Local Government Council }\end{array}$ & $\begin{array}{l}16-20 \\
\text { years }\end{array}$ & Male \\
\hline L1 & $\begin{array}{l}\text { Senior Administrative Officer (Estate), Jos } \\
\text { North Local Government Council }\end{array}$ & $\begin{array}{l}16-20 \\
\text { years }\end{array}$ & $\begin{array}{l}\text { Fema } \\
\text { le }\end{array}$ \\
\hline P1 & $\begin{array}{l}\text { General Manager, Sokus Nigeria Ltd (Real } \\
\text { Estate Developer) }\end{array}$ & $1-5$ years & Male \\
\hline $\mathrm{P} 2$ & $\begin{array}{l}\text { Director, Mamko Investment Co (Real } \\
\text { Estate Developer) }\end{array}$ & $\begin{array}{l}6-10 \\
\text { years }\end{array}$ & Male \\
\hline P3 & $\begin{array}{l}\text { Chief Executive Officer, J. Hausen Ltd } \\
\text { (Real Estate Developer). }\end{array}$ & $\begin{array}{l}26-30 \\
\text { years }\end{array}$ & Male \\
\hline
\end{tabular}

\section{PRESENTATION AND DISCUSSION OF FIELD DATA}

As indicated in the methodology section, the data for this study was generated through interviews conducted with government officials from the Ministries, Departments and Agencies that are responsible for the implementation of land subsidy policy in Jos. The questions that were put forward for discussion during the field study and the responses obtained are presented in this section. The interview data is presented alongside documentary evidence for corroborative purposes. In presenting the interview data the actual names of the respondents are represented by alphabets (see table 1) for the sake of anonymity and the purpose of confidentiality.

\subsection{Awareness on Land Subsidy Policy Provisions among the Respondents}

The first question that was put forward to government officers was: What is the responsibility of your organisation with regard to subsidising the cost of land for low income housing in Jos? This question was deliberately asked to assess the level of awareness of the respondents on the land subsidy policy. In response, F, an officer of the Federal Ministry of Lands, Housing and Urban Development in Jos said:

"The national housing policy requires my organisation to help provide land for housing in Jos. This is essential, particularly when considering that Nigeria's government wishes to fulfils the social objective of providing affordable housing to low-income households through a partnership with private institutions" (F). 
The officers (S1 \& 2) employed in the state government agencies demonstrated some level of awareness on the land subsidy policy. In their responses, they made reference to the national housing policy and the strategic plan for urban development and housing which was designed by the Plateau State Government in 2008, and the Greater Jos Master Plan documents which was produced in 2009: they confirmed that the role of their agencies in respect to subsidising the cost of land for housing were clearly spelled out in these two documents.

In the strategic plan for urban development and housing, the government had noted that the land owners in Jos were having a deep mistrust on government's land compensation arrangement and are often unwilling to part with their land for public projects. To address this concern, the government proposes to set up a special land compensation fund for the purpose of compensating (timely and adequately) those land owners whose lands may be acquired for public projects. There was a proposal by the state government to provide 2,000 serviced plots for housing in Jos. The government also proposed to set up a land bank and a forum for negotiation of land transaction. These measures were proposed to mitigate the obstacles to land supply in Jos (Government of Plateau State, 2008 pp. 31, 32). Similar proposals are contained in the Greater Jos Master Plan (Government of Plateau State, 2009) which was designed to span from 2009 to 2025.

The officers (L1 \& 2) employed in both Jos North and South Local Government Council (LGC) were able to comment with regards to subsidising the cost of housing to workers and the general public by the local government council authorities. This was clearly stated in the following responses:

"The LGC usually acquire land to sell to interested workers and residents around the Local Government Area (LGA)" (L1).

The response of L2 concurs with that of L1 above:

"....as usual the Council is helping people to have access to affordable housing through the provision of subsidised land" (L1).

The question that was presented to the developers was: Do you feel that government authorities in Jos are fully aware of their responsibilities regarding the subsidising of the cost of land for housing? The developers responded to this question as follows. P1 concurs with P2 in confirming that the housing policy says that the government will make land accessible to developers and that they felt that the relevant authorities in Jos were fully aware of this responsibility. P3 had a contrary opinion to that of his colleagues, he said:

"The housing policy requires state and local governments to design sub-policies and programmes simply because they have control over land in their territories ... I feel they don't really understand their role in that direction. They seem to understand the arrangement whereby the government will provide money for them to buy land and build instead of providing subsidies for developers to build" (P3).

\subsection{Strategies for Implementing Land Subsidy Proposals in Jos}

The government officers were asked to comment on the strategy adopted for the implementation of land subsidy proposal in Jos, and the question put forward to them was: what operational strategy has your organisation devised for the implementation of land subsidy proposals in Jos? In response to this question, F confirms that they were engaged in discussions with private developers with a view to help them acquire land from the native owners in Jos. F commented further that:

"We have had several meetings with land owners and the developers who showed interest on acquiring the land but the negotiation is not completed" (F). 
The respondents ( S1 \& 2) confirmed two strategies that are being used for the implementation of the subsidy proposal: one of which is "mediation" in land transaction as noted in the response given by S1 below

"Our strategy is to mediate and facilitate land purchase by bringing together private developers and land owners to ensure smooth transaction" (S1).

The second strategy is "persuading the government to act", as noted in the response of S1:

"The state government has expressed desire to partner with private developers to build houses in Jos. ...the Ministry has advised the government to acquire land so as to cut down development cost. ...it seems that the government (political leaders) is reluctant about our proposal. But we are persuading them to see reason in providing the subsidies" (S2).

The local government officers (L1\&2) confirmed that LGCs have adopted a strategy of "partnership" and through this, they have been subsidising the cost of land for housing to their workers and people residing in their area. This is confirmed in the following responses:

"The LGC has entered into a number of partnerships with land owners who are interested in selling their land and we have been able to acquire land to sell to interested workers and residents of the Local Government Area at subsidised price" (L1).

In his response of L2 concurs with L1:

“... as usual the Council is helping people to buy land at affordable price. We are in partnership with individuals and kinship groups who are willing to sell off their land. Through the partnership Council has acquired land and sold to interested workers and the public at a subsidised rate" (L2).

L2 adds that:

"Three hundred plots were produced at Mungel layout of which 150 were sold to the Council workers (at N150, 000 per plot - equivalent of US\$920) who indicated interest and the remaining were sold to the public" (L2).

L2 expands further on Council activities:

"In all the layouts that Council has produced and sold, infrastructure and services are usually provided." (L2).

L2 responded by saying that the idea of partnership between land owners and the Local Government Council became important so as to mitigate the challenges of acquiring land from native owners. The mitigation strategy adopted was that of allowing the land owners a feeling of involvement in the process of designing the laying out of the land they have decided to sell, and also by letting them get involved in the process of selling the land to buyers. This way, the local government council authorities will not buy the land as it did previously but will rather render a service to those land owners who wish to sell their land and charge a fee for the service rendered. The service rendered by the local government council will include the carrying out of a survey plan, producing a layout and marketing the plots to the public. However, the local government council is expected to take responsibility for basic infrastructure to the site. L2 also say that the local government council plans to collaborate with relevant agencies in the provision of infrastructure to the lay out. The response of L2 goes as follows: 
In previous layouts (citing an instance at Mungel), the Council provided a primary school and a health care facility for the residents. It plans to do same for the layout that will be produced from its partnership with the land owners (L2).

The responses of the local government councils officers (L1 and 2) indicate the fulfilment of housing provision roles to a high degree. However, the local government councils appear to be operating without having any form of partnership with state and federal government agencies as anticipated by the national housing policy. This lack of partnership between the local government councils and house builders suggest that those who buy housing plots from the local government councils usually build their houses through a self help approach. This approach does not provide the advantage that could arise from the economies of scale that is associated with the building of large number of housing.

\subsection{Access to Subsidised Land for Housing}

It is not clear from the preceding discussions, what the direction of federal government agency is, in regard to the implementation of the subsidy proposals in Jos. The state government officers (S1 \& S2) feel that house builders should bear the full cost of buying land for their projects and also providing basic services. In such case, the role of state government would be limited to facilitating the buying of the land. L1 \& L2 confirm that local government councils have made efforts in fulfilling the anticipated role of making housing provision less expensive but they do not create appropriate partnership with private house builders or housing corporations. The views and perspectives of developers are examined in relation to government's position. The question that was asked is: do you feel that relevant governmental agencies are sufficiently mitigating the obstacles for access to land for low income housing in Jos? Private developers were already building houses for sale in Jos but their experiences confirmed a lot of issues that constrain the land subsidy proposals in in Jos. P1 said:

"The issue of land is still a major problem in Jos... the land owners prefer to keep their land for ages without any improvement on it. The cost of land has been an issue, and it naturally inflates the cost of producing houses" (P1).

The response of $\mathrm{P} 1$ is a clear indication of the uncertainties and ambiguities that surround process of subsidising the cost of housing. P1 expresses concern on the failure of state government to provide affordable land so as to make housing affordable. The response of P1 also indicates that the proposed subsidy arrangement has offered no benefits to house builders because of a corrupt practice where the state government officers were allocating land to their associates as opposed to house builders who are interested in the provision of affordable housing.

Furthermore, P1 said that if a developer has to wait for government to provide the land, it will take decades. In his words, he aspires that:

“...we don't wait to get the government's allocation because it's always not coming. We usually look for land that can be purchased at reasonable cost, bearing in mind the affordability level of our buyers" (P1).

$\mathrm{P} 2$ concurs with $\mathrm{P} 1$ :

"The housing policy says that the government will make land accessible to developers but partnering with the government in this regard causes delay which have negative implication on the cost of houses we build in Jos" (P1).

P2 adds further that the experience of partnering with the government to acquire land for a new housing project was not a positive one. He stated that: 
"....at first, the government officers took some time to negotiate with the land owners and claimed to have concluded. ...it was on the day of payment that we got to understand there were pending issues. Fresh negotiation had to start and it took a year to acquire the land" (P2).

From the these responses, it can be deduced that instead of reducing the cost of acquiring land, the negotiating role of the government officers escalated the cost of compensation that was paid to the native land owners. According to P1 and 2, this happened to all developers that partnered with government at that time. The respondents regretted this and have decided never to allow government official to negotiate for them; they will rather do this themselves.

P3 feels that the involvement of government is rather discouraging the activities of developers. On this P3 clearly stated that:

"Housing is capable of stimulating the economy and creating demand for its product, and should be approached from that perspective. If the government were to subsidise the cost of land and infrastructure for developers, it must be done with some care otherwise the housing market will be distorted and killed" (P3).

The comments of P3 corroborate the concern raised by P1 and 2 above regarding government attempts to mediate in land transaction which resulted in delays and increases the cost of acquiring land. Elaborating further, P3 said:

"The city of Jos is being opened up substantially and the state government has acquired some parcels of land. If developers can pay for the compensation to enable them have the land it would be good. Such arrangement is more sustainable than waiting for the government to use its money to acquire land for developers. Let people earn their subsidy otherwise the housing market will never pick up" (P3).

P3 is clearly canvassing the withdrawal of government from the local housing market. P3 feels that this would create confidence for private house builders and even encourage them to supply houses based on demand. The position of $\mathrm{P} 1$ and $\mathrm{P} 2$ is contrary to the position of P3: they feel that subsidies are essential to ensure that houses are affordable to the low income population. They feel that government's role is necessary otherwise private house builders would not want to participate in the market place and only small number of houses will continually be supplied. Indeed this has been the case as evident from the inception of the subsidised housing policy (in 1991) to December 2014, where less than 500 housing units were built in Jos due to the limited activities of private house builders (FRN, 2014). The population in Jos has been on the increase, from 510,300 in 1991 (GEOHIVE, 2009) to 736,016 in 2006 (FRN, 2010) and this is creating more demand for housing, yet the formal housing supply is not keeping pace with this demand. As the population of Jos city is expected to grow to 2.7 million in 2025, government authorities have projected (on an average household size of six persons) the need of additional 237,379 housing units within the city (Government of Plateau State, 2009).

The shortage in the supply of low cost housing is likely to continue to push prices of formal housing upward. But if subsidies are provided, this is capable of attracting more house builders that could supply housing to meet the rising demand thereby bring down house prices to affordable levels. P2 laments the failure of government to subsidised land and infrastructure for housing in Jos. In his words, he stated that:

“...we used our money to buy land and provide roads, electricity and water. ... the cost incurred has to be transferred to the end users and the implication is that the three bedroom bungalow went up to N5.3million, three bedroom semi-detached house went for $\$ 4.8$ million and two bedrooms semi-detached was sold for N4.3million” (P2). 
As confirmed by $\mathrm{P} 2$, the result of lack of government subsidies had inflated the cost of houses built so much that a three bedroom bungalow was sold at $\$ 5.3$ as against the ceiling of $\$ 5$ million stipulated by the National Housing Policy. This regulation is not practical without the production subsidies being made available. The situation of house builders in Jos is similar to what occurred in other parts of Nigeria. For instance, a developer whose project was located at a city in the south west of Nigeria had to revise the price of houses from $¥ 3.9$ to $\$ 4.48$ million per housing unit to cover the additional costs. In this instance, the house builders incurred an additional cost in financing the acquisition of land and infrastructure. This was in addition to a price variation that arose due to delays that occurred while trying to access low interest loan from the Federal Mortgage Bank of Nigeria (FMBN) (Salami, 2009 p. 18).

\subsection{Land Registration and the Issuance of Title Documents}

The expectation of the National Housing Policy of 2006 is that the local authorities with their agencies will undertake reforms for the purpose of facilitating land registration and the issuance of title documents. This is necessary so as to help developers and individuals who need to register their land to obtain title documents, which are a crucial requirement for accessing loan from banks. The trends in land title (Certificate of Occupancy - $\mathrm{C}$ of O) applications that were submitted to the land registry (from 2000 to 2012) in Jos and the approvals received are presented in Figure 1. The performance of the land registry in approving of $\mathrm{C}$ of $\mathrm{O}$ was awfully poor during the period under consideration. Because of this poor performance, the respondents (S1 and L1 \& L2) who are employed in the state and local government land registries were asked a question: what measures have been introduced to improve on the arrangement for land registration and issuance of title documents to developers in Jos? S1 responded by commenting on the attempt of state government to improve the process of land registration. Thus:

"...the computerisation of the land registration process is already completed. A land data capturing system known as the Plateau Geographic Information System (PLAGIS) was designed and a new database is being created" (S1). 


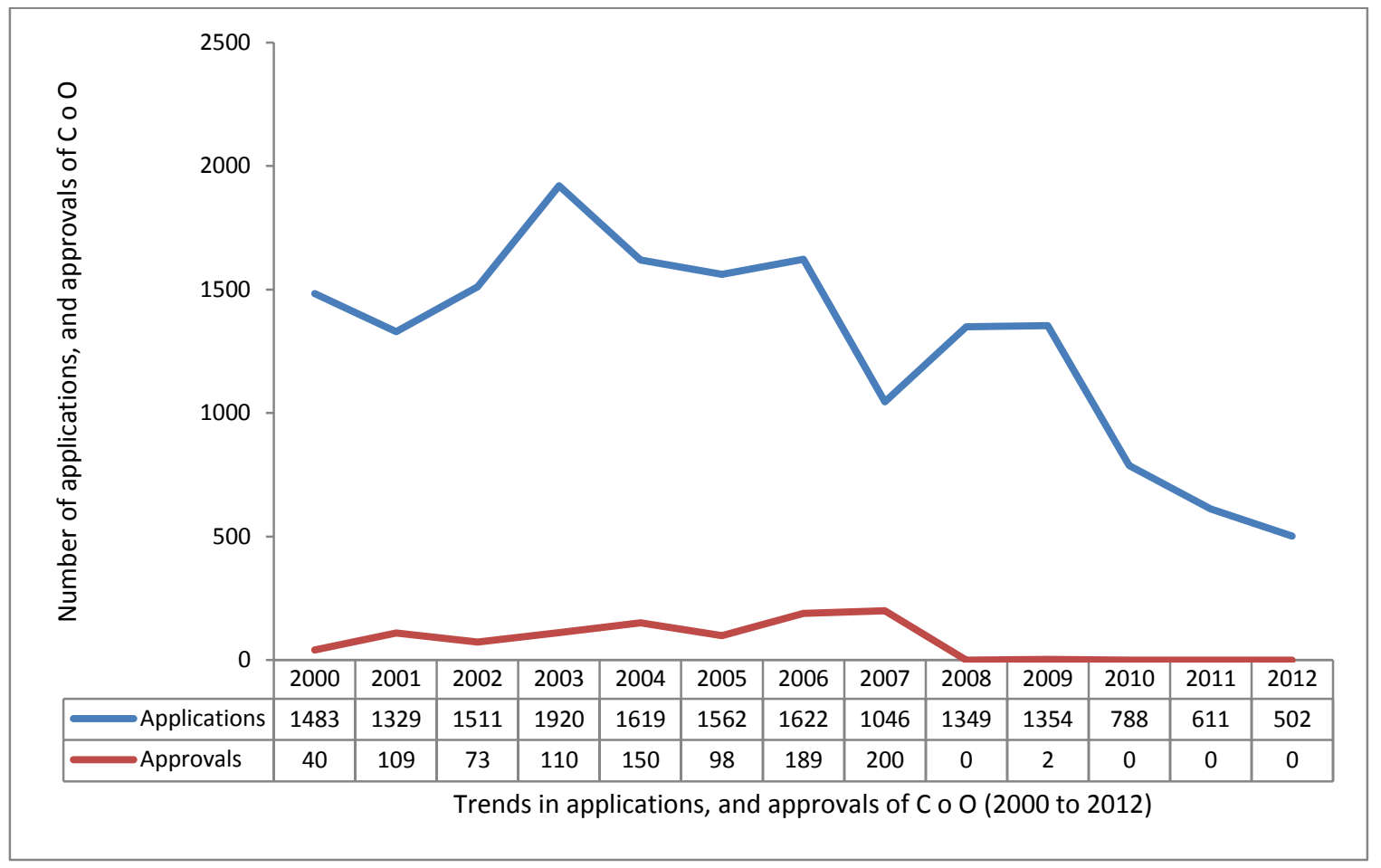

Figure 1: Trends in the application and approval of Certificate of Occupancy in Jos, Plateau State (2002 2012) (Field survey in Jos, 2014)

At the time of the field study, existing land records were being captured on Plateau Geographic Information System (PLAGIS) and S1feels that this will transform the land registration process from a manual to a computerised system. This should speed up land titling procedures and also reduce the delays being experienced by developers and individuals who need to obtain $\mathrm{C}$ of $\mathrm{O}$.

The use of computer in land title processing was already evident in one of the local government council as confirmed by L2. However, this development was not confirmed by L1. The local government council were rather involved with land acquisition for sale to the public instead of organising partnership of house builders. This role was confirmed by L1 \& 2 . At the state government level, the experiences of private builders show a great dissatisfaction with the role of government offices in facilitating access to land and titling processes. P1 said:

"The government in Jos is trying but there are issues that need to be dealt with. We applied for land title documents at a time when the government was planning to computerise the land registry. The Governor decided to place an embargo on the issuance of $\mathrm{C}$ of $\mathrm{O}$ for approximately three years. This action alone halted housing activities in Jos" (P1).

P2 concurred with P1 in this regard by saying:

"Land registration process has improved a little in Jos. It took about 12 months for us to obtain land title document after making application. Before submitting our application the state government suspended land 
registration process for three years. This created problems to developers who needed to obtain title documents at that time. It was a significant delay for investors" (P1).

There are number of issues that can be deduced from the responses of P1 and P2: the poor system of land registration is discouraging housing provision by private house builders; and the state government is abusing of the power vested on it by the LUA. These problems have caused substantial setback in the supply of subsidised housing in Jos.

\section{SYNTHESIS}

The field data examined in the course of the preceding discussions confirmed that government officers employed in local government councils, state government organisations and federal government agencies were aware of the policy on subsidising the cost of land and its expectations. The data confirmed that government officers have adopted some strategies including "partnering with land owners" to ensure the supply of housing land (as confirmed by Council officers), "persuading" government to act on the subsidy policy and "mediating" to facilitate smooth transaction of land between house builders and native land owners (as echoed in the responses of state and federal government officers).

Private developers were seen to have divergent views regarding the role of government officers in the provision of land and infrastructure subsidies. The views of private developers can be summarised four-folds: One, they felt that government (State and Federal) agencies in Jos do not fully comprehend their role in the arrangement of subsidising housing land and this is identified as a key variable influencing the supply of subsidies for low income housing. Though the local government authorities Jos are politically committed to providing land at subsidised rate, this does not appear to benefit private real estate developers. Notwithstanding, the councils have gained experience and also reasonably appreciated the practicalities of buying land from the land owners for the benefit of individuals that require affordable land.

Two, private developers felt that the federal and state government agencies in Jos are denying the responsibility placed on them by the national housing policy. With regard to making land affordable, the disposition of the federal and state government clearly indicates a lack of political commitment. Whilst the local government authorities tend to provide support directly to people through subsidising the cost of land and primary infrastructure provision, the state and federal agencies do not understand their role in this process. There is a problem of lack of transparency and accountability as confirmed by house builders. The arrangement at state government level tends to reflect corrupt practice in the sense that government officials prefer to allocate land to their associates who may not use it for the purpose of general housing provision. The private developers lamented over this lack of transparency and accountability.

Three, there is an indication of resistance to accept responsibility as spelt out in the national housing policy. This is confirmed by the reluctance of state and federal government authorities to accept, in clear terms, the responsibility for financing housing supply subsidies. Furthermore, private developers observed that government agencies seem to favour the arrangement whereby they will be allocated a budget to directly participate in acquiring land and building houses rather than providing development subsidy.

Lastly, there is a visible absence of supportive legislation to the proposed housing subsidy policy. The policy proposal that require government authorities to provide land subsidies for housing provision is not supported by a national legislation. In like manner, no legislation has been made by the law makers at the state government level in Jos. Also, the local government councils have not supported the decision with a byelaw. The interview responses suggested that federal and state government authorities in Jos are not willing to accept the 
responsibility of financing the cost of land and infrastructure subsidies. This happened because the decision is left at the discretion of government authorities, and in this case, they chose not to provide the subsidies.

\section{CONCLUSION}

This study sets out to achieve two objectives: The first was to examine how the policy proposals for subsidising the cost of land apply in the local context in Jos. The data examined in regard to this objective suggest the absence of a uniform approach to the application of the subsidy policy among the three tiers - federal, state and local - of government in Jos. The second objective was interested in scrutinising the variables influencing the arrangement for subsidising the cost of land in Jos. The data analysed confirms that the lack of proper understanding of land subsidy policy, the absence of political will on the part of State and Federal government agencies, the absence of transparency and accountability on the part of government officials, the absence of legislation in support of the subsidy policy, and bureaucratic constraints were the key variables influencing the subsidy arrangement in Jos. These conclusions are based on the data (interviews with government officers and private developers as well as documentary evidence) sets that were collected during a field study conducted in 2013 and 2014. We therefore recommend that future studies should examine the changes that have occurred in the housing policy setting in Jos and how these affect the supply of land and infrastructure subsidies for low income housing.

\section{ACKNOWLEDGEMENT}

The authors wish to thank all the government officers that participated in the interviews conducted during the field study in Jos. We also appreciate the rich comments made by two anonymous reviewers of our article. All sources of secondary materials used are duly acknowledged.

\section{REFERENCES}

Adiuku-Brown, M. E. (1999). The dangers posed by the abandoned mine ponds and the lotto

Agbosu, L. K. (1988). The Land Use Act and the State of Nigerian Land Law. Journal of African Law, Vol.32 No.1, pp.1-43.

Agunbiade, M. E. Rajabifard, A. and Bennet, R. (2014). Land administration for housing production: An approach for assessment, Land Use Policy, Vol.8, 366-377.

Alexander, M. J. (1990). Reclamation after tin mining on the Jos plateau Nigeria. Geographical journal, Vol.156 No.1, pp.44-50.

Augustinus, C. and Deininger, K. (2006). Innovations in Land Tenure, Reform and Administration in Africa. In: Mwangi, Esther (2006). Land Rights for African Development from Knowledge to Action. Collective Action and Property Rights (CAPRi) Policy Briefs, pp. 14-16.

Daniel, M. M. (2015). Enabling the Supply of Urban Housing in Developing Countries: The Experience of Nigeria. LAP LAMBERT Academic Publishing, Germany (ISBN-13: 978-3659745294).

Daniel, M. M. (2014). Evaluating the Determinants for Access to Subsidised Mortgage Housing in Jos, Nigeria. Journal of Construction in Developing Countries, 19(2), 87-109, 2014

Dung-Gwom, J. Y. (2001). Delay in obtaining planning permission by private developers in Jos, Nigeria. Journal of Environmental Sciences, Vol.5 No.1, pp.103-124.

Dung-Gwom, J. Y. (2007a). Urban Renewal in Jos - Bukuru Metropolis. Paper Presented at the MCPD of Nigerian Institutions of Estate Surveyors and Valuers, Leadership Institute, Tudun Wada, Jos, Plateau State, Thursday October, 25.

Dung-Gwom, J. Y. (2007b). Post mining operations and the environment. Paper Presented at the 38th Annual Conference of the Nigerian Institute of Town Planners, Asaba, Delta State. October 31 to November 4.

Francis, P. (1984). 'For the Use and Common Benefit of All Nigerians': Consequences of the 1978 Land Nationalization. Africa: Journal of the International African Institute, Vol.54 No.3, pp.5-28. 
Francis, P. (1986). Land Nationalisation and Rural Land Tenure in Southwest Nigeria. International Livestock Centre for Africa.

FRN (1978). Land Use Act 1978. Nigeria.

FRN (1991). National housing policy.

FRN (2006). National housing policy. Abuja, Federal Ministry of Lands, Housing and Urban Development.

FRN (2010). The 2006 population and housing census. Abuja: National Population Commission.

FRN (2012). National housing policy. Abuja, Federal Ministry of Land, Housing and Urban Development.

FRN. (2014). Registered estate developers. Federal Mortgage Bank of Nigeria. Last accessed 10/10/2015 at www.fmbn.gov.ng/doc/RegisteredEstateDevelopers.

GEOHIVE. (2009). Nigeria population statistics. Last accessed 08/10/15 at http://www.geohive.com/cntry/nigeria.aspx

Government of Plateau State in Nigeria (2008). Four Year Strategic Plan for Urban Development and Housing in Plateau State (2008-2011).

Government of Plateau State in Nigeria (2009). Greater Jos master plan 2008 - 2025,

Ministry of Land, Survey and Town Planning, Jos, Nigeria.

Gray, D. E. (2009). Doing research in the real world. Sage Publications Ltd.

Ikejiofor, Uche (1998): Access to Land, Development Control and Low-income Housing in Abuja, Nigeria: Policy, Politics and Bureaucracy, Planning Practice \& Research, Vol.13

No.3, pp.299-309.

Kameri-Mbote, Patricia (2006). Gender Issues in Land Tenure under Customary Law. In: Mwangi, Esther (2006). Land Rights for African Development from Knowledge to Action. Collective Action and Property Rights (CAPRi) Policy Briefs, pp.11-13.

Kiduanga, J. (2014). Managing land for developing Dodoma, the capital city of Tanzania. Critical analysis of the role of Dodoma Municipal Council and capital development authority. Journal of Sustainable Development, 7(5),140-149.

Mamman, A. B. (2012). Land Management in Nigeria. Available at: http://www.onlinenigeria.com/land/. (Accessed 29 October, 2014)

Mallo, S. J. (2012). The Socio-Economic Impact of Artisanal Mining in Kuru (Naraguta Sheet 168) Plateau State, North Central Nigeria. Continental J. Engineering Sciences, Vol.7 No.3, pp.27-32.

Mbinji, J. (2006) Getting Agreement on Land Tenure Reform: The Case of Zambia. In: Mwangi, Esther (2006). Land Rights for African Development from Knowledge to Action. Collective Action and Property Rights (CAPRi) Policy Briefs, pp.33-35.

NGO News Africa (2012). Nigeria: NGOs decry unregulated mining in Jos. Available at:

http://ngonewsafrica.org/archives/300 (Accessed 26 April, 2014).

Onibokun, A. G., Agbola, T. and Labeodan, O. (1989). World Bank assisted site-and-services projects: Evaluation of Nigeria's experiment. HABITAT INTL, Vol.13 No.3, pp.51-64.

Oshio, P. E. (1990) The Indigenous Land Tenure and Nationalization of Land in Nigeria, B.C. Third World L.J., Vol.10 No.1, pp.43-62.

Otubu, A. K. (2010). Land Reforms and the Future of Land Use Act in Nigeria. Nigerian Current Law Review, (NIALS) 2007 - 2010, pp.1-16.

Ouedraogo, Hubert (2006a). Decentralization: An Enabling Policy for Local Land Management. In: Mwangi, Esther (2006). Land Rights for African Development from Knowledge to Action. Collective Action and Property Rights (CAPRi) Policy Briefs, pp.24-26.

Ouedraogo, Hubert (2006b).The Land Policy Process in Burkina Faso: Building a National Consensus. In: Mwangi, Esther (2006). Land Rights for African Development from Knowledge to Action. Collective Action and Property Rights (CAPRi) Policy Briefs, pp.36-38.

Raufu, A. (1999). Tin mining wrecking beautiful Jos. African business, Vol.243 No.40. 
Salami, S. (2009). Operatives of the economic and financial crimes commission is set to move against debtors of the federal mortgage bank of Nigeria as the deadline for the payment of the non-performing loans draws to a close. The business eye - Nigeria's investigative business journal, Vol.3 No.39, pp.16-20.

Stanfield, J. D., Underwood, J., Gunaskera, K., and Ernst, C. (2008). Land Registration and Land Fraud in the United States. Paper presented to the Seminar on Risk Reduction in Land Fraud 22-23 October, 2008, Selangor Darul Ehsan, Malaysia.

Taylor-Powell, E., Renner, M. (2003). Analyzing qualitative data. University of Wisconsin-- Extension, Cooperative Extension.

Umezulike, I. A. (2011).Nigeria's major land reforms and adaptive strategies of harnessing its social justice. Lagos, Nigeria, Nigerian Institute of Advanced Legal Studies. Public lecture series.

Van Asperen, P. (2014). Evaluation of innovative land tools in sub-Saharan Africa: Three cases from a periurban context. Evaluation of Innovative Land Tools in Sub-Saharan Africa: Three Cases from a PeriUrban Context. The Series Sustainable Urban Areas, 43, the Netherlands: Delft University Press.

UNECE (2005). Social and Economic Benefits of Good Land Administration. Working Party on Land 2nd Edition, Administration, New York and Geneva.

UNECE (1996) Land Administration Guidelines: With Special Reference to Countries in Transition. Report No: ECE/HBP/96, New York and Geneva.

UN-HABITAT (2001).National trends in housing production practices. Volume 4: Nigeria. UH-Habitat Information Services Section, Nairobi, Kenya.

UN-HABITAT (2004). Enabling shelter strategies: Design and implementation guide for policy makers. Nairobi, Kenya, United Nations Human Settlements Programme. Quick policy guide series (Volume 2).

UN-HABITAT (2006). Enabling shelter strategies: Review of experiences from two decades of implementation. Nairobi, Kenya, United Nations Human Settlements Programme.

Wapwera, S.D., Parsa, A., Egbu, C. O., and Ayanbinpe, G. M. (2011). Abandoned mines, homes for the people: case study of Jos Tin mining region, in: COBRA RICS Construction and Property Conference, University of Salford, September 12-13.

Wily, L. A. (2003) Community-based land tenure management: Questions and answers about Tanzania"s new Village Land Act, 1999. International Institute for Environment and Development (IIED). Issue paper no. 120. 